\title{
Post It, Share It, Like It: Motivations behind Wedding Posts on Social Media among Nigerian Youth
}

\section{Dr. Saudat Sallah ABDULBAQI (Mrs.)}

Department of Mass Communication, Faculty of Communication and Information Sciences, University of Ilorin, Ilorin, Nigeria

sau_baqi@yahoo.com

\author{
Abdulgaffar Olawale ARI KEWUYO \\ Faculty of Communication and Media Studies, Eastern Mediterranean University, Famagusta, North Cyprus, via \\ Mersin 10, Turkey \\ arikewuyoa@gmail.com
}

Olabola Taye OMI SORE

Faculty of Communication, Cyprus International University, Lefkoşa, via Mersin 10, Turkey omisoreolabola@gmail.com

\begin{abstract}
The Nigerian wedding industry is one of the most lucrative business industries in the country today; this is as a result of the frequency of the event which has become a global phenomenon. This study therefore seeks to find out the motivations as well as psychological effects behind posting, liking and sharing wedding pictures and videos on social media platforms among Nigerian youth. A random sampling of $350 \quad(n=350)$ Nigerian youth was carried out. Findings reveal that the act of posting, liking or sharing of wedding pictures and videos on social media platforms by the youth could translate to their desire to publicize the designers and decorators due to their love for what they wear. The study is also able to infer that quite a number of Nigerians who post wedding pictures and videos on social media do so with the intention of showing the kind of extravagant life style they live.
\end{abstract}

Keywords: Social media, weddings, instagram, youth, advertising

\section{I ntroduction}

Social media has continued to play a significant role in the development and sustenance of human life in different ramifications (Lambert, 2016). It has become a dominant platform on the internet and as such majority of internet users are active users of the various social media platforms, this has given reasons for its description as a platform that facilitate information exchange among humans(Kaplan \& Haenlein, 2010). This information, therefore, comes in different formats such as pictures, graphics, videos, voice notes and texts among others. Social media has further enhanced interpersonal communication, while reducing the cost of accessing information (Fotis, Buhalis, \& Rossides, 2011). This is as a result of the availability of news and other day to day information required for optimum performance of human life (i.e. weather forecast, traffic update etc.). With the aid of social media, online communities have emerged in order to educate and enlighten individuals in understanding their rights and responsibilities about the various forms of harassments they experience (Arikewuyo, Özad, \& Abdulbaqi, 2017). This has helped reduce the trend of physical and sexual harassing being experienced mostly by girls and women. 
Social media has facilitated efficiency and promptness in various professions including journalism (Sheffer, 2012). With the aid of the platforms, media organisations and practitioners have boosted their followership and work efficiency. Social media has continued to be regarded as a veritable tool in all human facets due to its highly impactful roles on human lives (Devi, 2017), this includes but not limited to its use in promoting and propagating the ideologies of various political parties (Arikewuyo \& Udende, 2017).Social media also creates an avenue for networking as well as building and maintaining relationships with the ability to overcome all forms of barriers regardless of time, location or cost (Lin \& Lu, 2011). With twitter recording well over 41.7 million profiles (Kwak, Lee, Park, \& Moon, 2010) as well as the recent public announcement of Facebook recording 2billion accounts, social media has further enhanced interpersonal communication between friends, families, groups and organizations. As a result of the various forms of discussions and debates that taking place on the platforms, social media has been somewhat referred to as a violent medium (Recuero, 2015).

As an active audience platform, social media has given an opportunity to its users to become key players in determining what content they get exposed to, how they get it and on what platform they get it. "...social media is defined by the key modalities and platforms like Facebook and Twitter which feature participatory, collaborative usercreated content (UCC)" (Hjorth \& Hendry, 2015, p. 1). For instance, majority of the contents on the platforms are created by the users, this further afford the users the opportunity to become content providers and consumers at the same time. Social media has significantly changed the perceptions and minds of the media audience most especially in areas of message conception, transmission and interpretation (Tang \& Cooper, 2017).Social media has become a means of self-promotion as individuals use the platform in promoting ideas and ideologies as well as get the public informed or educated about a certain belief or phenomenon (Elmer, 2015). Social media has brought a great paradigm shift to the mode and pattern of interpersonal communication as well as group communication (Farman, 2015). This is as a result of the opportunity the platform creates for its users to have group discussions at various levels. i.e. WhatsApp, BlackBerry and Facebook group chat among others. Religion has also received a boost through the radical use of the various social media platforms in educating and reeducating citizens(Abdulbaqi \& Arikewuyo, 2015). As such, social media has become quite relevant in many spheres of human endeavours.

Today, one of the most lucrative sectors in the Nigerian business sphere is the wedding industry. Weddings have become regular events across the various cultural circles in Nigeria. This has made wedding business significantly lucrative by creating jobs for young Nigerians who have now become stake holders in providing services that make weddings become memorable and successful. These services include photography, decoration, catering, videography as well as the entire event planning among others. This has also added some form of excitement to the various social media platforms especially Facebook, Instagram and Snapchat as there are now several existing Facebook, Instagram and Snapchat platforms with millions of followers that specialize on posting and re-posting wedding pictures and videos. There has been quite a few number of studies relating to social media and weddings (Pan, Zheng, Wilkie, \& Shahabi, 2013; Zarro, Hall , \& Forte, 2013), but none of these studies analyses the motivations behind the use of wedding pictures on social media. Therefore, this study attempts to fill the missing gap by finding out the motivation behind posting, liking and sharing of wedding pictures on social media platforms by Nigerian youth. It also seeks to find out the effects these pictures and posts have on other young Nigerians who are either about getting married or still in search of their romantic partners. The study also examines the feelings and impressions of Nigerian youths when they see wedding posts on the various social media platforms. 


\section{Literature Review}

\section{A Review of Social Media and Advertising}

Social media has become a highly dependable advertising and marketing tool for all kinds of goods and services (Chan \& Guillet, 2011). Social media has facilitated high consumer information, knowledge and aided decision making process of active and prospective clients due to its ability to afford the consumer adequate knowledge and information in the decision making process. Social media platforms have created an opportunity for the growth of businesses and as well building new brands (Erdogmus \& Cicek, 2012). Through social media, new as well as up and coming brands have been able to create a market for themselves, thereby increasing their publicity and enhancing their sales.

Social media does not only establish a communication channel between the client and the service provider, it is a critical platform that creates an opportunity for consumer to consumer interaction, thereby enabling consumers to exchange ideas, opinions as well as interact about their satisfaction or otherwise on a common product or service (TyreeHageman, Kurani, \& Caperello, 2014).Social media has become a tool for driving business traffic to various organizations. For instance, companies like Amazon, Ali Express etc. have various social media platforms where they market products and goods available on their websites. Lester (2012), states that "Social media venues are used for posting digitally produced items, driving traffic to the site, soliciting customer response, and generally creating a buzz thorough out the market" (p. 117). For Nigerian weddings, the key players involved in the process such as photographers, decorators, masters of ceremony, food vendors etc. engage in displaying their past and ongoing works on their platforms. These displays help in attracting more customers and clients, thereby serving as a means of direct and indirect advertisements. They post the pictures and short video of their clients on their Instagram, Facebook or Twitter platforms and ensure that the services they rendered are written/displayed with their company name or logo boldly displayed. This is a form of marketing, advertising as well as introducing their brands to potential customers.

\section{Fig 1: Display of Nigerian Bride on I nstagram}

Figure 1 is the Instagram handle of a prominent Nigerian photographer displaying a

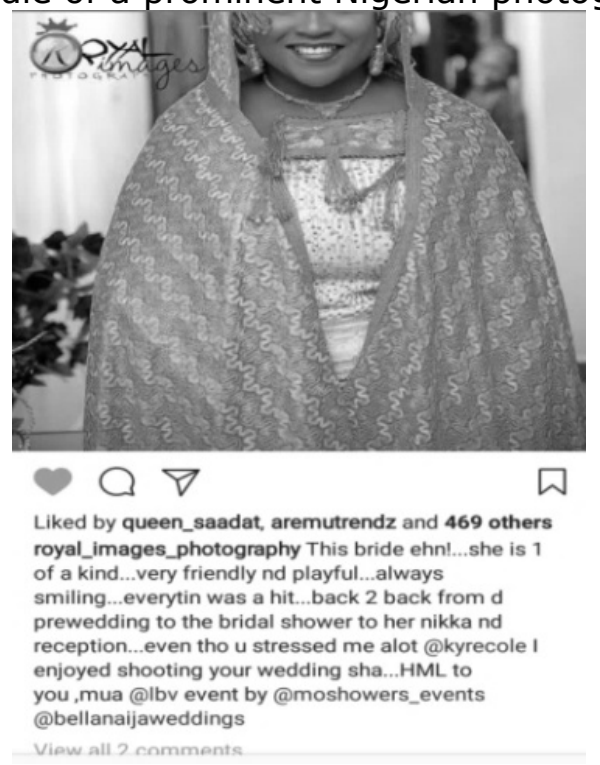

Nigerian Bride in her traditional attire. This illustrates a common practice by Nigerian wedding vendors, as detailed captions usually accompany such picture/s or video/s with 
other vendors being tagged. This serves as a form of social media marketing and advertising strategy for all the parties involved (Oyekunle \& Arikewuyo, 2014). Hogan (2010), explains further that "...those who view and react to this content may be different from those for whom it was intended" (p. 381), as such, the purpose of the message may be misconstrued or entirely lost.This is a common practice that usually boost the sales or patronage of the vendors as well as enhances service provider-client relationship. Some of these wedding pictures are also posted to help influence the choice of other would-be clients, thereby facilitating patronage for the company, organization or the individual vendor (Barans, 2006).

\section{1st Century Nigerian Weddings}

Weddings are generally regarded as one of the most essential celebrations in the human life, as it is a day an individual and allies look forward to because it marks the beginning of a new and essential chapter in such a person's life(Massimi, Harper, \& Sellen, 2014). Westernization and globalization have succeeded in changing the way weddings are celebrated today globally and mostly in Nigeria. Nigerian weddings used to involve various cultural and traditional rites, but today, the trend has changed as a result of the influx of the western cultures into the system (Hollos \& Whitehouse, 2008). Religion, civilization as well as loss of traditional or ancestral values have also contributed to the erosion of the traditional wedding rights. "The western wedding has been fashioned by many people in Nigeria as the modern type of wedding and they believe that marriage is not complete without the western type of wedding" (Odinye \& Odinye, 2012, p. 112). This is an indication of the extinction of the cultural norms and values as a result of civilization, westernization and global erosion of cultural values (Eicher \& Tonye, 1995). Technology is therefore, contributing to the change in scope and belief of cultural values, thereby replacing it with man-made and artificial inventions. This has contributed to the promotion of cross cultural weddings (Nelsona \& Otnesb, 2005)

Today, weddings have now taken different forms, modes and styles(Shida, 1999), this can be largely be linked to modernity and social developments. Though extravagant weddings are discouraged by many, the societal trends, status and requirements has enhanced extravagant weddings in different ramifications (Engel, 1984). This ranges from ambiguous forms of wedding decorations, dresses, accessories, make-up, food/drinks, photography and a host of others. At some instances extravagant weddings are a result of the need for the bride, groom or parents from both families to match up with their colleagues or not to fall below a mostly self-incurred societal requirement or standard.

As the society continues to grow, the rate at which individuals spend on weddings is becoming alarming. Only in America alone, about $\$ 34.9$ billion was spent on weddings in the year 2005; this is as a result of the ascription that weddings are celebrated once in a human's life. As such, all efforts and finances are put into it to make the day highly memorable regardless of the repercussions after such events. For instance, modern day photography and other forms of documentation alone take a huge amount of the wedding budget; this is due to the new trends in the motion and still picture industry. This assertion is authenticated by Beeck and Horn (2010), as they state that "weddings are the primary source of revenue within the photography industry, generating $45.5 \%$ of industry revenue" (p. 26). Couples thereby budget a huge amount of money to get their desired ascetics, the quality and beauty derived from such services gives them the zeal, drive and motivation to post it as well as encourage friends and associates to share and like the videos and pictures on their social media platforms.

The main focus of modern day Nigerian wedding is the reception ceremony, and this usually requires the highest chunk of the budget (Adler \& Chienm, 2004). At times, 
couples encourage their most important guests to attend the reception and significant effort is put into it as the focal point. The wedding industry has now grown such that individuals and companies now specialise in the organisation of such events and are thereby known as wedding planners (Blakely, 2008). Their main objective is to recruit and organise vendors like MCs, Photographers, Decorators etc. on-behalf of their client and according to their taste, budget and requirements (Johnston, 2006). This has contributed tremendously to the growth and development of the wedding industry across board (Lau \& Hui, 2010).

\section{Methodology}

This study attempts to establish the motivations behind posting, sharing and liking social media wedding posts among Nigerian youth. Participants are drawn through a simple random sampling of 350 Nigerian youth who are active users of the various social media platforms. A 5 Likert scale questionnaire was randomly administered to the sample which was drawn out of $(\mathrm{N}=3,758)$ members of the "2016 Batch B" National Youth Service corps members NYSC. According to Krejcie and Morgan's (1970) sample size table, a sample size of three hundred and fifty youth $(n=350)$ was adopted.

\section{Demographics and their Means}

From the analysis, $51.9 \%$ sample comprises of female respondents while $46.9 \%$ of the respondents are male. The age distribution shows that the majority of the respondents are below the age of $30(23-39=63.3 \%, 18-23=27.1 \%)$, while age groups $30-35$ and $36-40$ recorded a \% population of $7.5 \%$ and $2.1 \%$ respectively. Marital Status of the respondents indicates a largely single population with $37.2 \%$ of the respondents single while 43.5 of the respondents are engaged. $17.2 \%$ of the respondents are married with $2.1 \%$ divorced.

Investigations into the frequency of use of social media by respondents show that social media is often used as $34.2 \%$ of the respondents use social media almost always and $42.9 \%$ using the platform often. $16.3 \%$ use social media sometimes, $5 \%$ seldom use it, and $1.7 \%$ never use it. WhatsApp ranked as the most used social media platform with $55.4 \%$ of the respondents, Facebook $(20.4 \%)$ and Instagram $(15.8 \%)$ are next ranked while Twitter and Snapchat have the least followers with $4.2 \%$ each.

Table 1: Correlation Analysis of Effect of Wedding Posts on Social Media $* \mathrm{P} \leq 0.05 * * \mathrm{P} \leq 0.01$

\begin{tabular}{llllllllll}
\hline \multicolumn{1}{c}{ Item } & Mean & SD & 1 & 2 & 3 & 4 & 5 & 6 & 7 \\
\hline Class & 3.15 & 1.69 & 1 & & & & & & \\
Marriage feelings & 3.00 & 1.25 & 0.37 & 1 & & & & & \\
Emotionally down & 3.54 & 1.17 & 0.23 & 0.48 & 1 & & & & \\
Perfect marriage & 3.57 & 1.18 & 0.26 & 0.38 & 0.66 & 1 & & & \\
Lasting wedding & 3.75 & 1.15 & 0.21 & 0.31 & 0.54 & 0.69 & 1 & & \\
Classy wedding & 3.16 & 1.30 & 0.28 & 0.31 & 0.37 & 0.51 & 0.52 & 1 & \\
Elaborate wedding & 3.16 & 1.29 & 0.29 & 0.31 & 0.39 & 0.53 & 0.46 & 0.78 & 1 \\
\hline
\end{tabular}

The correlation analysis result in table measures the correlation between class and effect of Nigerian wedding posts on social media. Results indicate that there are seven (7) positive correlations ( $r>0.50)$, and no negative correlation between respondents

Table 2: Percentage of Respondents who Post Wedding Pictures for Certain Motivations

\begin{tabular}{lllllll}
\hline Item & & $\begin{array}{l}\text { Strongly } \\
\text { Agree }\end{array}$ & Agree & Undecided & Disagree & $\begin{array}{l}\text { Strongly } \\
\text { Disagree }\end{array}$ \\
\hline $\begin{array}{l}\text { Show their } \\
\text { lifestyle }\end{array}$ & extravagant & 20.9 & 32.1 & 16.7 & 22.6 & 7.7 \\
\hline
\end{tabular}




\begin{tabular}{llllll}
\hline Show off their elegance & 15.3 & 31.4 & 14.8 & 31 & 7.4 \\
Show off what they wear & 19.6 & 31.7 & 15.2 & 27.8 & 5.7 \\
Show they are classy & 17 & 37 & 16.5 & 23.5 & 6.1 \\
Show they are rich & 16.7 & 39.4 & 7.1 & 27.6 & 9.2 \\
Show off their partner & 20.7 & 38.4 & 15.5 & 17.7 & 7.8 \\
$\begin{array}{l}\text { Tell the world they } \\
\text { married }\end{array}$ & 32.1 & 36.3 & 11.4 & 14.3 & 5.9 \\
\hline
\end{tabular}

Table 2 is a descriptive analysis of the motivations behind posting wedding pictures and videos on the various social media platforms. Majority of the respondents representing $53 \%$ are in tandem with the fact that quite a number of users post wedding pictures and videos on the social media in order to directly or indirectly display their extravagant life style while $46.7 \%$ also concur that posting wedding pictures and videos on social media is a means of displaying their various forms of elegance. Respondents that agree that they show off what they wear at weddings on social media are of the majority in this study as they represent $51.3 \%$ while $54 \%$ state that they post such pictures and videos in other to show that they are classy. Wealth is another reason people post wedding pictures on social media platforms, with $56 \%$ in agreement with this assertion, while $59.1 \%$ and $68.4 \%$ state that they post pictures on social media in order to show off their partner as well as tell the world they are married respectively

Table 3: Percentage of Respondents who get affected by Wedding Post on Social Media

\begin{tabular}{|c|c|c|c|c|c|}
\hline Item & $\begin{array}{l}\text { Strongly } \\
\text { Agree }\end{array}$ & Agree & Undecided & Disagree & $\begin{array}{l}\text { Strongly } \\
\text { Disagree }\end{array}$ \\
\hline Emotionally down & 6.1 & 16.5 & 15.2 & 41.7 & 20.4 \\
\hline Every marriage is perfect & 7.8 & 14.7 & 9.9 & 48.3 & 19.4 \\
\hline Only classy wedding lasts & 9.5 & 15.9 & 10.3 & 39.3 & 25.0 \\
\hline I must have a classy wedding & 11.6 & 15.9 & 12.9 & 33.6 & 25.9 \\
\hline $\begin{array}{l}\text { I must have an elaborate } \\
\text { wedding }\end{array}$ & 10.8 & 28 & 1.6 & 34.1 & 25.5 \\
\hline
\end{tabular}

Table 3 presents the level of agreement of respondents on how posts on social media affect them in various ways and forms. According to the findings, $61.67 \%$ of the respondents representing majority disagree that the get emotionally depressed when other people post wedding pictures and videos on social media while $67.7 \%$ disagree that the aesthetics in the wedding pictures and videosmake them feel every marriage is perfect. Results in the study also reveal that $64.3 \%$ disagree that only classy weddings last while $59.5 \%$ also disagree that they must have classy weddings as a result of the pictures and videos they view on social media. Also, $59.6 \%$ disagree that they must have elaborate weddings due to the colorful and beautiful wedding pictures they view on social media.

Table 4: Percentage of Respondents who have Motivations for Identifying with Wedding Posts

\begin{tabular}{|c|c|c|c|c|c|c|}
\hline I tem & & $\begin{array}{l}\text { Strongly } \\
\text { Agree }\end{array}$ & Agree & Undecided & Disagree & $\begin{array}{l}\text { Strongly } \\
\text { Disagree }\end{array}$ \\
\hline $\begin{array}{l}\text { To advertise the } \\
\text { planner }\end{array}$ & event & 14.8 & 38.8 & 11.6 & 28 & 6.8 \\
\hline To advertise the MC & & 12 & 24.4 & 17.9 & 37.6 & 8.1 \\
\hline
\end{tabular}




\begin{tabular}{lrlllll}
\hline $\begin{array}{l}\text { To advertise } \\
\text { photographer }\end{array} \begin{array}{l}\text { To advertise the food } \\
\begin{array}{l}\text { To } \\
\text { vendors }\end{array}\end{array}$ & 11.5 & 21.8 & 7.7 & 39.3 & 19.7 \\
$\begin{array}{l}\text { To advertise the designers } \\
\text { Helps the decorator }\end{array}$ & 16.2 & 37.6 & 6.8 & 26.1 & 13.2 \\
\hline
\end{tabular}

Table 4 is a breakdown of the level of agreement of respondents to motivations for liking, commenting and sharing wedding pictures and videos on social media. $53.6 \%$ of the respondents agree that they like, share or post wedding pictures in order to identify with the event planner while $45.7 \%, 53 \%$ and $59 \%$ disagree that their main reasons for liking, sharing and posting wedding pictures and videos are to advertise the master of the ceremony, photographer or food vendors respectively. Findings in this study also reveal that a reasonable percentage of the respondents with $53.8 \%$ and $51.9 \%$ agree that they like, share and post wedding pictures and videos on social media in order to advertise the designers and decorators.

\section{Discussion}

This study has been able to empirically find out the motivations behind posting, sharing, and liking wedding pictures on social media platforms. Findings in the study reveal several reasons and motivations that spoor Nigerian youth to post wedding pictures and videos on social media platforms. This study has been able to infer that quite a number of Nigerian youth who post wedding pictures and videos on social media do so with the intention of showing the kind of extravagant life style they live. This could be as a result of wanting to be identified with the upper class in the society, to gain respect or because of the need to be seen as unique. Nigerians also post on social media platforms in other to show what they wear. This could range from expensive dresses, jewelries, shoes, head ties, wrist watches and make up among others. Revelations from this study also indicate that one of the motivations for social media wedding posts by Nigerian youth is as a result of their wish to show off their partner or generally announce their marriage. This has been said to also have psychological effects on the users of the social media platform (Choudhury, Gamon, Counts , \& Horvitz , 2013). Sometimes this is associated with excitement, the drive to show to whom they are married to or make the larger public become aware of their marriage. They also intend to show their wealth which is unusually obvious in almost all aspects of the wedding. This varies from the personalities who attend the wedding, the location, decoration, and wears among others.

According to the findings in this study, wedding posts on social media in quite a number of instances do not negatively affect the youth emotionally. As a result, this study is able to deduce that wedding posts on social media do not significantly affect the emotions of many Nigerian youth. As such, many of them watch these pictures and videos to gratify various needs and desires which does not negatively affect their emotions. This categorically translates to the fact that viewing other people's colorful or attractive wedding posts do not generally result into emotional depression of the viewer. Findings in this study is also able to create a clear understanding that not every marriage is perfect, this could be said to be in tandem with Vaillant and Vaillant (1993). This is based on the fact that Nigerian youth understand that there is a difference between wedding and marriage. As such, because a wedding ceremony was highly colorful, attractive and all over the various social media platforms does not in-turn translate into a perfect or successful marriage. Similarly, revelations from the study infer that classy weddings do not also determine the success of the marriage and as a result it is not highly compulsory they also must have classy or highly cerebral wedding ceremony.

This study also finds out that Nigerian youth in order to identify with various actors and stakeholders post, like and share wedding pictures and videos on social media. For 
instance, some of the social media users like to identify with wedding planners most especially. This could be as a result of the fact that wedding planners are key stake holders in Nigerian weddings as the quality of the vendors they higher for their client go a long way to determine the success or otherwise of the event. On one hand, social media users who post on the platforms do not necessarily post, like or share in order to advertise the Master of the Ceremony, photographer or food vendors, but could just post, like or share in order to identify with them or as a result of the beauty or their love for such picture or the personalities involved. On the other hand, their act of posting, liking or sharing could translate to their desire to publicize the designers and decorators due to their love for what they wear or the aesthetic beauty of the design and decoration.

\section{Conclusion and Recommendation}

This study has been able to infer that there are quite a number of motivations behind posting, liking and sharing wedding pictures and videos on social media platforms by Nigerian youth. These motivations range from their desire to advertise, market, publicize, create a brand, identify or rejoice the wedding planner, photographer, videographer, fashion designer or even the celebrant themselves. Also, the study has been able to come up with findings that social media users who view wedding posts are not usually emotionally disturbed by what they see on the platforms.

Generally, it is quite clear that social media plays various prominent roles in awareness, marketing, advertising and general publicity of its various contents. It is therefore recommended that due to the influx of users of various kinds on social media platforms, youth should be more careful of their posts on the platforms. Based on the fact that other users are not generally impressed by the display of extravagant lifestyles displayed on social media. There should be minimal display of personal wedding pictures or videos on social media except for the purpose of advertising, marketing or publicity of certain vendors who contributed to the success of the event.

\section{References}

Abdulbaqi, S. S., \& Arikewuyo, A. O. (2015). ICT as Vehicles for Interaction among Muslim Women in Ilorin: An Appraisal of Social Media for Islamic Propagation. Ilorin: Centre For Ilorin Studies.

Adler , H., \& Chienm, T. C. (2004). The Wedding Business A Method to Boost Food and Beverage Revenues in Hotels. Journal of Foodservice Business Research, 7(1), 117125.

Arikewuyo, A. O., \& Udende, P. (2017). (In) validating Cohen's Assertion on AgendaSetting Theory using Media Coverage and What People Think about Muhammadu Buhari's Campaign Mantra. Novena Journal of Communication, 3.

Arikewuyo, A. O., Özad, B., \& Abdulbaqi, S. S. (2017). Role of Social Media in Eradicating Violence among Young Nigerian Females: A Study of Nigerian Students in Eastern Mediterranean University. 6th International Conference on Gender Studies: Gender, Conflict, War and Peace. Famagusta: Center For Women 's Studies - CWS.

Barans, S. B. (2006). A Privacy Parardox: Social Networking in the US. First Monday, $11(9-4)$.

Beeck, T., \& Horn, G. (2010). Wedding Bells Are Ringing. The RMA Journal, 23-7.

Blakely, K. (2008). Busy Brides and the Business of Family Life: The Wedding-Planning Industry and the Commodity Frontier. Journal of Family Issues, 29(5), 639-662.

Chan, N. L., \& Guillet, B. D. (2011). Investigation of Social Media Marketing: How Does the Hotel Industry in Hong Kong Perform in Marketing on Social Media Websites? Journal of Travel \& Tourism Marketing, 28, 28:345-368,. 
Choudhury, M., Gamon, M., Counts , S., \& Horvitz , E. (2013). Predicting Depression via Social Media. Seventh International AAAI Conference on Weblogs and Social Media , (pp. 1-10).

Devi, K. N. (2017). Social Media Aided Sentiment Analysis in Forecasting. Online Journal of Communication and Media Technologies, 7(1), 163-173.

Eicher, J. B., \& Tonye , V. (1995). Why do they call it Kalabari? Cultural Authentication and the Demarcation of Ethnic Identity. Dress and Ethnicity, 139-164.

Elmer, G. (2015). Going Public on Social Media. Social Media + Society, 1-2.

Engel, J. W. (1984). Marriage in the People's Republic of China: Analysis of a New Law. Journal of Marriage and Family, 46(4), 955-961.

Erdogmus, I. E., \& Cicek, M. (2012). The Impact of Social Media Marketing on Brand Loyalty. Procedia - Social and Behavioral Sciences, 58, $1353-1360$.

Farman, J. (2015). Infrastructures of Mobile Social Media. Social Media + Society, 1-2.

Fotis, J., Buhalis, D., \& Rossides, N. (2011). Social Media Impact on Holiday Travel Planning: The Case of the Russian and the FSU Markets. International Journal of Online Marketing, 1(4), 1-19.

Hjorth , L., \& Hendry, N. (2015). A Snapshot of Social Media: Camera Phone Practices. Social Media + Society, 1-3.

Hogan, B. (2010). The Presentation of Self in the Age of Social Media: Distinguishing Performances and Exhibitions Online. Bulletin of Science, Technology \& Society, $30(6), 377-386$.

Hollos, M., \& Whitehouse, B. (2008). (In) Fertility and the Modern Female Life Course in two Southern Nigerian Communities. Ethnology, 47(1), 23-43.

Johnston, L. (2006). 'I Do Down-Under': Naturalizing Landscapes and Love through Wedding Tourism in New Zealand. ACME: An International E-Journal for Critical Geographies, 5(2), 191-208.

Kaplan, A. M., \& Haenlein, M. (2010). Users of the World, Unite! The Challenges and Opportunities of Social Media. Business Horizons, 53, 59-68.

Kwak, H., Lee, C., Park, H., \& Moon, S. (2010). What is Twitter, a Social Network or a News Media? Proceedings of the 19th International Conference on World Wide Web.

Lambert, D. (2016). What role does Social Media Play in Today's Refrigeration Industry? International Journal of Refrigeration, 68(5-6).

Lau , C. K., \& Hui, S.-H. (2010). Selection Attributes of Wedding Banquet Venues: An Exploratory Study of Hong Kong prospective Wedding Couples. International Journal of Hospitality Management, 29, 268-276.

Lester, D. H. (2012). Social Media: Changing Advertising Education. Online Journal of Communication and Media Technologies, 2(1), 116-125.

Lin, K.-Y., \& Lu, H.-P. (2011). Why People use Social Networking Sites: An Empirical Study Integrating Network Externalities and Motivation Theory. Computers in Human Behavior, 27, 1152-1161.

Massimi, M., Harper, R., \& Sellen, A. (2014). "Real, but Glossy" - Technology and the Practical Pursuit of Magic in Modern Weddings. Romance, 854-865.

Mcquail, D., \& Windahl, S. (1993). Communication Models for the Study of Mass Communications. London, England: Longman.

Nelsona, M. R., \& Otnesb, C. C. (2005). Exploring Cross-Cultural Ambivalence: A Netnography of Intercultural Wedding Message Boards. Journal of Business Research, 58, $89-95$.

Odinye, I., \& Odinye, I. (2012). Western Influence on Chinese and Nigerian Cultures. $A$ New Journal of African Studies, 9(1), 108-115.

Oyekunle, R. A., \& Arikewuyo, A. O. (2014). Trust in The E-Market Place: A Case Study Of OLX.NG Users. International Conference on Science, Technology, Education, Arts, Management and Social Sciences (pp. 555-558). Ado-Ekiti: iSTEAMS Research Nexus Conference. 
Pan, B., Zheng, Y., Wilkie, D., \& Shahabi, C. (2013). Crowd Sensing of Traffic Anomalies Based on Human Mobility and Social Media. 21st ACM SIGSPATIAL International Conference on Advances in Geographic Information Systems, (pp. 344-353).

Quan-Haase, A., \& Young, A. L. (2010). Uses and Gratifications of Social Media: A Comparison of Facebook and Instant Messaging. Bulletin of Science, Technology \& Society, 30(5), 350-361.

Recuero, R. (2015). Social Media and Symbolic Violence. Social Media + Society, 1-3.

Sheffer, M. L. (2012). Name Brand: The Rise of the Independent Reporter through Social Media Dr. Brad Schultz, University of Mississippi. Online Journal of Communication and Media Technologies, 2(3), 93-112.

Shida, K. (1999). The Shintoist Wedding Ceremony in Japan: An Invented Tradition. Media, Culture \& Society, 21(2), 195-204.

Tang, T., \& Cooper, R. (2017). The Most Social Games: Predictors of Social Media Uses During the 2016 Rio Olympics. Communication \& Sport, 1-23.

Tang, T., \& Cooper, R. (2017). The Most Social Games: Predictors of Social Media Uses During the 2016 Rio Olympics. Communication \& Sport, 1-23.

TyreeH. J., Kurani, K. S., \& Caperello, N. (2014). What does Community and Social Media use Look LikeAmong Early Pev Drivers? Exploring how Drivers Build an Online Resource Through Community Relations and Social Media Tools. Transportation Research Part D, 33, 125-134.

Vaillant, C. O., \& Vaillant, G. E. (1993). Is the U-Curve of Marital Satisfaction an Illusion? A 40-Year Study of Marriage. Journal of Marriage and Family, 55, 230239.

Zarro, M., Hall , C., \& Forte, A. (2013). Wedding Dresses and Wanted Criminals: Pinterest.com as an Infrastructure for Repository Building. Seventh International AAAI Conference on Weblogs and Social Media, (pp. 650-658).

Dr. Saudat Salah ABDULBAQI, had all her university degrees in Communication with a bias for Development \& Behavioural Change Communication, Public Speaking, Gender Communication, Health Communication, Research and Public Relations. She has put in an active 17 years into the teaching of Mass Communication and its composite courses within and outside Nigeria. She has attended many national and international academic conferences, workshops and seminars. Saudat had well researched papers published in reputable, peer-reviewed journals and books. She is a well-travelled scholar with a very friendly nature.

ABDULGAFFAR OLAWALE ARIKEWUYO, is a Ph.D. student at the Faculty of Communication and Media Studies of the Eastern Mediterranean University, located in the Turkish Republic of Northern Cyprus and a Lecturer at the University of Ilorin, Ilorin, Nigeria. He holds a Diploma, Bachelor and Masters in Mass Communication from the Bayero University and University of Ilorin respectively. He has published in Local, National and International Journals. Abdulgaffar is a professional media practitioner and has attended Local, National and International Conferences. He's research interests includes Social Media, Phenomenology, Ethnography, Political Communication, Health Communication, Radio Studies and Media Cultivation

OLABOLA TAYE OMISORE, has a master's degree in Drama at University of Pretoria and another master's degree in Communication and Media Studies at Eastern Mediterranean University in North Cyprus. She is currently a doctoral candidate in the Faculty of Communication and Media Studies at Cyprus International University in Turkish Republic of Northern Cyprus. Her research interests are African women studies, journalism, misogyny and hip hop and, education in developing nations, journalism. 